\title{
Gıda ve yem mikrobiyoloji laboratuvarlarında seçilmiş riskler ile risk kaynaklarına ilişkin kontrol mekanizmaları
}

\author{
Nuray Gamze Yörük' ${ }^{1}$ (D), Erdem Danyer ${ }^{2}$ () \\ ${ }^{1}$ Kocaeli Gıda Kontrol Laboratuvar Müdürlüğü Mikrobiyoloji ve Seroloji Birimi, Kocaeli, Türkiye \\ ${ }^{2}$ Veteriner Kontrol Merkez Araştırma Enstitüsü Müdürlüğü, Ankara, Türkiye
}

Geliş Tarihi / Received: 12.09.2019, Kabul Tarihi / Accepted: 26.05.2020

\begin{abstract}
Özet: Risk, bir kurumun kuruluş amaçları ile stratejik amaç ve hedeflerine ulaşmasına, temel faaliyetlerinin yerine getirilmesine engel olabilecek veya beklenmeyen zararlara yol açabilecek durum ya da olaylardır. ISO / IEC 17025 Test ve Kalibrasyon Laboratuvarlarının Yeterliliği İçin Genel Şartlar Standardının 2017 yılı revizyonunda risk belirlenmesi, laboratuvar kalite yönetiminin bir parçası olmuştur. Bu çalışmada, gıda ve yem analizlerinin yapıldığı bir mikrobiyoloji laboratuvarında muhtemel riskler ve etkilerinin belirlenmesi ile risk değerlendirme skorlarına göre aksiyon alınmasına ilişkin çalışma anlatılmıştır. Tespit Edilen Riskler; Strengths (Güçlü Yönler), Weaknesses (Zayıf Yönler), Opportunities (Fırsatlar), Threats (Tehditler) faktörlerinin belirlendiği SWOT analizi yapılarak değerlendirilmiştir. Ardından, değişen faaliyetlere ve olaylara bağlı olarak belirli zaman aralıklarında risklerin etki ve olasılıkları gözden geçirilerek risk skorları hesaplanmıştır. Risk skorunda elde edilen sonuçlara göre riskin türü, risklere verilecek cevaplar, açıklamalar ve alınacak ek önlemler ile risk eylem planlarının yapılıp yapılmayacağı belirlenmiştir. Risk değerlendirmesi, 1-5 puan arasındaki risk olasılığı ile risk şiddetinin çarpımı sonucunda elde edilen 1-25 puan arasındaki risk skoru puan skalası üzerinden denk gelen sayıya göre hesaplanmıştır. Araştırma sonucunda, eski ve yeni sistem ile çalışan laboratuvara ait risk puanları sırasıyla $9.84 \pm 0.55$ ve $4.92 \pm 0.27$ puan olarak belirlenmiştir $(p<0,05)$. Risk değerlendirmesinin uygun ve etkin bir şekilde yapıldığı zaman laboratuvarın gelişmesine katkı sağladığı görülmüştür.
\end{abstract}

Anahtar kelimeler: ISO 17025, risk değerlendirmesi, risk etkisi, risk skoru, SWOT analizi

\section{Control mechanisms about selection risk with risk resources in the food and feed microbiology laboratories}

\begin{abstract}
Risk is a situation or event that may result in unexpected harm, or may prevent an organization from reaching their founding purposes, strategic goals, and targets, and fulfilling their main operations. Risk assessment and identification of opportunities were a part of laboratory quality management in the 2017 revision of the General Requirements for the adequacy of ISO / IEC 17025 Test and Calibration Laboratories. This study is to describe the possible risks and their impact, uncovering opportunities on food and feed microbiology laboratories and to take action according to risk assessment scores. Strengths, Weaknesses, Opportunities, Threats, or SWOT analysis were used to assess the risks identified. Then, risk scores were calculated by reviewing the effects and possibilities of risks at certain time intervals depending on the changing activities and events for the risks. According to the results obtained in the risk score, it was determined whether the risk action plans will be made with the type of risk, the answers to the risks, explanations and additional measures to be taken. For this purpose, determined risks should first be evaluated. For evaluated risks, the impact and probability of risks should be reviewed and risk scores should be calculated in certain time intervals depending on changed activities and events. According to results of risk scores (1-25), it should be determined whether risk action plans will be made with the risk type, risk responses, remarks and additional measures to be taken. In the result of this study, risk assessment has been performed according to the risk score, a number between 1-25 on a score scale obtained from the multiplication of a risk probability value between 1-5 points and the risk impact. As a result of the research, the risk score of the laboratory working with the previous system $9.84 \pm 0,55$ and $4.92 \pm 0.27$ new system was determined as and point respectively $(p<0.05)$. It is thought that when the risk assessment is done properly it will contribute to the development of the laboratory.
\end{abstract}

Key words: ISO 17025, risk assessment, risk impact, risk score, SWOT analysis

\section{Giriş}

Laboratuvar testlerinin doğruluğu ve güvenilirliği, analizler ve hizmetler alanında hizmet alacak kişi/ kişiler/firmalar tarafından karar vermede önemli bir rol oynar. Bu testler, özellikle, analitik öncesi, analitik dönem ve analitik sonrası aşamalara dayanmakta, ilgili işlemlerin detaylı bir şekilde yapılması ve bunlar için nasıl aksiyon alınması gerektiğinin bilinmesi gerekmektedir. Bu nedenle, ISO 17025: 2017 (ISO 2017) ile ISO 31000:2018 (ISO 2018) gereklilikleri, 
risk yönetimi araç ve prosedürlerinin kullanımına uyulmasını tavsiye etmektedir (Vasilnakova 2014).

Laboratuvarlarda her aşamada çeşitli risklerle karşı karşıya kalınmaktadır. Güvenilir test sonuçları elde etmek için tüm adımlarda tam hata tespiti ve buna yönelik önlemler gerekir (Vasilnakova 2014; Neogi ve ark. 2016).

Özellikle, mikroorganizmalarla etkileşime giren laboratuvarlar, patojenlerin kullanımına bağlı olarak bazı potansiyel risklere sahiptir. Biyogüvenlik ve biyogüvenliğin tanınmasını arttıracak emniyet yönetim sistemi, tehlike olasılığını önlemek ve patojenle uğraşan araştırmacıların güvenliğini sağlamak için kurulmalı ve uygulanmalıdır (Lee ve ark. 2014).

Risk, gelecekte meydana gelebilecek bir olayın istenmeyen sonuçlara yol açabileceği varsayımına dayanmaktadır. Herhangi bir risk yönetimi sürecinin nihai amacı, riskleri tanımlamak, değerlendirmek, hafifletmek ve/veya ortadan kaldırmaktır (Vasilnakova 2014).

Risk yönetimi, tehlikelerden doğabilecek risklerin belirlenmesi ve bunların ortaya çıkışını önlemeye yönelik bir erken uyarı sistemidir (Uslu 2016). Risk yönetiminin başta gelen hedefleri laboratuvarların tümünü kapsayan bir uyum içinde, zararlara mani olma faaliyeti ve düzeltici aktivitelerden oluşmaIıdır (Griffin 2011; Uslu 2016). Bu sistem sayesinde laboratuvar çalışanları, laboratuvarın tüm sistemi ile numuneler için olası riskleri azaltılmakta ve böylece güvenli bir ortam oluşturulmaktadır.

Risk yönetimi kritik noktaları belirleyebileceğimiz çeşitli aşamalardan oluşmaktadır (Rejda 2010). Bu aşamalar aşağıda belirtilen başıklar altında tanımlanabilir:

a) Tehlike olasılığı ve buna bağlı oluşabilecek risklerin belirlenmesi: Tehlike unsurlarının oluşturabileceği muhtemel riskler belirlenir ve bu riskleri içeren risk grupları listelenir.

b) Belirlenen risklerin analizi veya değerlendirilmesi: Riskler belirlenip, tanımlanarak risk analizleri risk değerlendirme matriksi ile gerçekleştirilir. Risk analizi ile riskin şiddeti ortaya koyulur. Risk tespitinin yapılmasıly risklerden her birine tehlike değeri verilmelidir. Bunun için risk hesaplamasında; riskle karşılaşma intimali, karşılaşma sıklığı, karşılaşabilecek bireyler ya da analizler ile gerçekleşme ihtimali fazla olan risk kaynağı tespit edilir.

Yapılan değerlendirmelerin sonunda riskler yüksek önem derecesinden düşük önem derecesine doğru sıralanır (SWOT analizi). Gerçekleşme ihtimali fazla ve meydana getirebileceği zararı yüksek olan risk/riskler kritik önem derecesinde sayılarak çözüme gidilir.

c) Riskleri değerlendirme sistemleri veya metotlarının belirlenmesi: Burada risk kontrol ve risk finansmanı stratejileri genellikle bir arada çalıştırılmaktadır. Risk kontrolünün sağlanması ile risklerin önlenmesi ve/veya etkisinin azaltılması mümkündür. Risk kontrolü; riskin kabullenilmesi, riske girmeme, kayıpların önlenmesi veya en aza indirilmesini içermektedir (Aksay ve ark. 2003).

d) Riske karşı uygulama: Belirlenen risklere karşı uygun olan stratejilerin gerçekleştirilmesidir.

e) Kontrol ve denetimlerin takibi: Bu aşamada uygulanan analizler her basamakta kontrol edilerek, sonuçları değerlendirilmektedir (ECRI 2003).

f) Geri bildirim ve hataları giderme: Yapılan risk analizleri sonucunda, risk yönetimi süreci planlanan zamanlarda sürekli kontrol edilerek, geri bildirim yöntemiyle gerekli düzenlemeler veya iyileştirmeler uygulanmalıdır. Risk analizi süreci, tespit edilmiş risk/riskler ile ilgili kayıpların etkisini ve sıklığını ortaya koyan çalışmaları içeren süreçtir (ECRI 2003; Griffin 2011; Uslu 2016).

Bu çalışmada, gıda ve yem numunelerinin çaıışılığı mikrobiyoloji laboratuvarlarında karşılaşılabilecek riskler ve etkilerinin belirlenmesi hedeflenmiştir. Bu amaçla, laboratuvarın belirlenmiş olan bu risklerle risk analizi yapılmadan önceki işleyişi ile risk analizi yapıldıktan sonraki işleyişinin, risk değerlendirme skorlarına göre karşılaştırılması, risklerin önlenmesi ve/veya ortadan kaldırılmasına yönelik yapılması gereken çalışmalar yürütülmüş, hesaplamalar yapılarak sonuçlar değerlendirilmiştir. Ayrıca yapılan çalışmada, risklerin yönetilmesi sonucunda oluşacak olumlu etkileri ile sağlayabileceği olası kazançları olan fırsatlarda belirlenerek sunulmuştur.

\section{Gereç ve Yöntem}

Çalışmada, gıda ve yem numuneleri çalışan mikrobiyoloji laboratuvarları için risk teşkil edebilecek tüm durumlar tek tek tanımlanarak, tehlikeler belirlenmiş ve 25 maddeden oluşan bir risk analizi değerlendirmesi yapılmıştır. Çalıșmanın anlaşılabilir olması ve sadeleşmesi için sadece müdahale ile değişiklik görülen 13 adet risk bu çalışmaya konu edilmiştir. Bu araştırmada, laboratuvarda oluşması muhtemel riskler SWOT analizi yapılarak listelenmiş olup, risk analizleri için laboratuvarın daha önceden risk faktörleri hesaba katılmaksızın yapılan risk analizi sonuçları ile risk faktörleri ve yapılacak çalışmalara yön verildikten sonraki analiz sonuçlarının Failure Mode and Effect Analysis (FMEA) Risk Değerlendirme 
kriterlerine göre yorumlanmasına yer verilmiştir. Laboratuvarda yapılan çalışmada ISO 31000:2018 (ISO 2018) ve ISO 31010:2017 (ISO 2017) standart- ları temel alınarak kullanılan risk değerlendirme kriterlerinin ortaya çıkma olasılığı/etkisinin kriterleri Tablo-1'de sunulmuştur.

Tablo 1. Risk Değerlendirme Kriterleri Ortaya Çıkma Olasılığı (İhtimal)/ Yarattığı Etki (Şiddet) (Eurolab 2017).

\begin{tabular}{|c|c|c|}
\hline $\begin{array}{l}\text { Derecesi } \\
\text { (Puanı) }\end{array}$ & Olasılık & Etki \\
\hline $\begin{array}{l}\text { Çok Yüksek } \\
\text { (5) }\end{array}$ & $\begin{array}{l}\text { Riskin ortaya çıkma ola- } \\
\text { sılığı çok yüksek (\%80- } \\
\% 100)\end{array}$ & $\begin{array}{l}15 \text { (Risk Şiddeti 5, olasılığı } 3 \text { olan risklerde risk skoru } 15 \text { ise yüksek risk (önemli risk) } \\
\text { olarak değerlendirilecektir.), } 16 \text { ve } 20 \text { olan risklerdir. Riskin oluşması durumunda sonu- } \\
\text { ca yıkıcı olumsuz etki vermesi, faaliyetlerin durdurulma gereksiniminin doğması. Mad- } \\
\text { di kayıplar olabilir. Ek kontrol faaliyetleri belirlenmelidir. }\end{array}$ \\
\hline $\begin{array}{l}\text { Yüksek } \\
\text { (4) }\end{array}$ & $\begin{array}{l}\text { Riskin ortaya çıkma ola- } \\
\text { sılığı yüksek (\% 51-\%79) }\end{array}$ & $\begin{array}{l}\text { Risk skoru } 12 \text { (Risk şiddeti } 4 \text { ve olasıllığı } 3 \text { olan risklerin skoru } 12 \text { ise yüksek risk (önemli } \\
\text { risk) olarak değerlendirilecektir.), Risk oluşması, Stratejik ve birim hedeflerine ulaşmada } \\
\text { yüksek düzeyde olumsuz etkisi olabilir. Birim süreçleri olumsuz etkilenir. Maddi kayıp- } \\
\text { lar olabilir. Ek kontrol faaliyetleri belirlenmelidir. }\end{array}$ \\
\hline $\begin{array}{l}\text { Orta } \\
(3)\end{array}$ & $\begin{array}{l}\text { Riskin ortaya çıkma } \\
\text { olasılığı ancak belirli du- } \\
\text { rumlarda gerçekleşebilir } \\
(\% 50)\end{array}$ & $\begin{array}{l}\text { Risk skoru 8, 9, 10, } 12 \text { ve } 15 \text { olan risklerdir. Orta düzey risklerin etkilerini düşürmek için } \\
\text { faaliyetler başlatılmalıdır. Riskin oluşması Stratejik ve birim hedeflerine ulaşmada ve } \\
\text { hizmetlerin sunulmasında belirli düzeyde etkisi olabilir. Risk azaltma önlemleri zaman } \\
\text { alabilir. Ek kontrol faaliyetleri belirlenmelidir. }\end{array}$ \\
\hline $\begin{array}{l}\text { Düşük } \\
(2)\end{array}$ & $\begin{array}{l}\text { Riskin ortaya çıkma ola- } \\
\text { sılığı düşük. (\%20-\%49) }\end{array}$ & $\begin{array}{l}\text { Risk skoru 3, 4, } 5 \text { ve } 6 \text { olan risklerdir Riskin oluşması süreçlerde hafif olumsuz etki } \\
\text { oluşturabilir. Süreç performansında çok az düşme olabilir. Ek kontrol faaliyetleri belir- } \\
\text { lenebilir. }\end{array}$ \\
\hline $\begin{array}{l}\text { Çok Düşük } \\
\text { (1) }\end{array}$ & $\begin{array}{l}\text { Riskin ortaya çıkma ola- } \\
\text { sılığı yok denecek kadar } \\
\text { azdır. (\%1-\%19) }\end{array}$ & $\begin{array}{l}\text { Risk skoru } 1 \text { ve } 2 \text { olan risklerdir. Çok düşük risklerde süreç devam ettirilir. Riskin oluş- } \\
\text { ması halinde sistem performansı dikkate değer düzeyde etkilenmez. Mevcut kontrol } \\
\text { faaliyetleri ile sürece devam edilmelidir. }\end{array}$ \\
\hline
\end{tabular}

Tablolar, risk öncelik puanlarının, potansiyel hata etkileri ve yapılacak iyileştirme faaliyetleri sonrasında yapılan iyileştirme oranlarını görebilmek amacıyla, bütünselliği sağlamak açısından, literatürle de uyumlu şekilde tek bir parça halinde verilmiştir.

Laboratuvarlardaki tüm bu değerlendirmelerin yapılmasında ise en önemli süreçlerden olan gerek reaktif ve gerekse proaktif dönemde risk unsurları açısından tehlikeli olabilecek bileşenleri içerisinde barındıran laboratuvar sürecine yönelik olarak Pillay ve Wang (2003)'ın belirttiği şekilde FMEA çalışması yapılmıştır. FMEA çalışması genellikle beş adımdan oluşmaktadır. Bunlar;

1. Riske konu olan kaynağın ve kaynağa ait sürecin belirlenmesi: FMEA uygulanacak kaynağa ait risk şiddeti yüksek sürecin belirlenmesidir.

2. FMEA çalışmasının yapıldığı laboratuvar orta$\mathrm{mı} /$ personeli: FMEA için, çeşitli analiz yöntemlerinin kullanıldığı çeşitli laboratuvar ortamı (risk unsurları göz önüne alınmadan önce ve sonra) ya da personelinin belirlenmesi gerekmektedir.

3. FMEA yapılmasına konu olan kaynağa ait sürecin grafik olarak sunumu: Sürecin işletilmesine dair akış diyagramının belirlenmesidir.

4. FMEA analizi aşaması: FMEA çalışması sırasında listelenen hata çeşitlerine yönelik olarak FMEA çalışmasında bulunan ekip muhtemel her hata türünü gözden geçirerek oluşabilecek hataların potansi- yel etkilerini belirler. Hata türü belirlendikten sonra hata türünün şiddet, olasılık ve fark edilebilirliğinin, olası nedenleri ile birlikte genellikle karar ağacı kullanarak bulunması aşamasıdır.

5. Aksiyon alma ve analiz sonuçlarının hesabı: Elde edilen verilere göre bir plan dâhilinde problem çözümüne yönelik hedefler ortaya koyulması, yüksek riskli olan hata türlerinin ortadan kaldırılması veya azaltılması için hareket tarzının belirlenmesidir. Hedef olarak temelde risk oluşturabilecek hata türleri komple ortadan kaldırılmaya çalışılmalıdır (Mc Dermott ve ark. 2009). Çalışmada değerlendirilen riskler aşağıda sıralanmıştır.

\section{Personel Kaynaklı}

Laboratuvarlar yüksek sağlık riski barındıran tehlikeli ve riskli ortamlardır. Laboratuvar güvenliğinin sağlanması için çalışma alanlarında ve takip eden süreçlerde personelin karşılaşabileceği risklerin kontrolü ve bertaraf edilmesi gerekmektedir. Laboratuvar içinde görev alan her çalışanın, öncelikli laboratuvar güvenliği hakkında bilgi sahibi olması, karşılaşabileceği potansiyel tehlike ve risklere karşı duyarlı olması, acil durumlarda neler yapması gerektiğini bilmesi ve kurallara dikkatle uyması gerekmektedir. Koruyucu çalışma uygulamaları benimsenmeli ve kişisel koruyucu ekipmanlar çalışma esnasında muhakkak kullanılmalıdır. Bu ekipmanlar gözlük, maske, eldiven ve iş önlüğü gibi donanımlardır. Saçlar dağı- 
nık ve çalışmaya mani olmamalıdır. Çalışma bitiminde her materyal, cihaz ve aletler uygun yöntemlerle temizlenip kaldırılmalıdır. Standartlara uygun giysiler seçilmeli (önlük, galoş, terlik vb.), laboratuvar çaış̧ma alanında yiyecek ve içecek bulundurulmamalıdır. Numuneler ya da reaktifler potansiyel bulaşma kaynağı olarak görülmeli çalışma sırasında örnek ve reaktiflerle direkt temastan kaçınılmalı, eldiven kullanılmalıdır, direkt temas sonrasında eller muhakkak uygun temizleyiciler ile yıkanmalıdır. Analizlerin gerçekleştirildiği kısımlar laboratuvar personelinin hareketini engellemeyecek şekilde ergonomik olarak tasarlanmalıdır. Tezgâh ve yüzeyler kirli alanlar olarak kabul edilmeli, bunlarla temas halinde eller dezenfektanlarla dezenfekte edilip yıkanmalıdır. Bu düzenlemelerin amacı tüm çalışanların güvenli bir iş ortamında çalışmasının sağlanması ile doğru ve güvenilir sonuçları olan analizleri gerçekleştirmektir. Bununla birlikte güvenliğin laboratuvar üst yönetiminden işçisine kadar herkesin sorumluluğunda olduğu unutulmamalıdır (ECRI 2003; Uslu 2016).

Yeterli personel ile iş yükünün orantılı paylaşımı ile hizmette kalite sağlanmalı ve aktif bir hata bildirim sistemi geliştirilmelidir. Laboratuvar teknik personeli, ortaya çıkabilecek her türlü hata ve bunlara bağlı meydana gelebilecek riskleri azaltmak için yalnızca mesleki görevlerini yerine getirmelerinden sorumlu tutulmalıdır. Stres, hataların belli başlı sebepleri arasında sayıldığından, stres kaynakları tespit edilmeli ve strese yol açan etkenleri minimize edecek tedbirler hayata geçirilmelidir (Özata ve Altunkan 2010).

\section{Laboratuvar Kaynaklı}

Analiz süresince uygulanan kalite çalışmaları içerisinde laboratuvar süreçleri de yer almaktadır. Bu süreçte temel hedef doğru, güvenilir ve kesin laboratuvar sonuçlarının zamanında hizmet alanlara sunulabilmesidir. Aşağıda belirtilen bu süreçlerden herhangi birinde ortaya çıkabilecek bir problem kaçınılmaz olarak test sonuçlarında hatalara yol açmaktadır. Laboratuvar hataları, numunelerde hangi analizin isteneceğinden sonuçların rapor edilip, uygun olarak yorumlanmasına kadar olan süreçte meydana gelen eksiklik ya da kusur olarak tanımlanabilir. Yapılan farklı çalışmalardan elde edilen sonuçlar laboratuvar hatalarının dağılımının; analiz öncesi evre \%46-68, analiz evresi \%7-13, analiz sonrası evre \%18-47 olarak belirtmektedir (Uslu 2016). Gıda/yem mikrobiyolojisi laboratuvarlarında analize ait numunelerin değerlendirilmesi oldukça karmaşık bir yöntem olup çok yönlü bir yaklaşım gerektirir. Laboratuvar süreci belli başlı üç kısımdan oluşur (Bolayırlı 2013).

\subsection{Analiz Öncesi Süreç}

Bu aşamada numunenin kabulü, sıcaklık derecesi ölçümü ya da etiket bilgilerindeki ısıyla uyum sağlayıp sağlamadığının kontrolü, geliş saati, orijinal ambalaj olup olmadığı, steril kap ya da ambalajlarla transferin gerçekleştirilip gerçekleştirilmediği, numuneye ait analiz isteklerinin yapılması, etiketlenmesi, numunelerin toplanması ve ilgili laboratuvara uygun koşullarda ulaştııılmasını içerir. Hata/hataların sıklıkla karşılaşıldığı aşamadır. Bu aşamada karşılaşılacak hataların yüksek oranda oluşma ihtimali ve kontrolü laboratuvar personeline bağlı olan bir durum değildir. Bu evrede görülebilen başııca sorunlar; analiz taleplerinde ve numune tanımlanmasında yapılan hatalar, uygun olmayan (laboratuvara ulaştıııldığında numunenin mikrobiyolojik analizler için uygun ısıda olmaması, çatlak ya da sızıntılı bir ambalaj ile getirilmiş olması vb.) numune alımı, numunelerin steril olmayan kaplarda olması ya da orijinal ambalajın delik, çatlak, patlamış olduğunun farkına varılmadığı durumlardır. Ayrıca, numunelerin istenilen analizler için yeterli miktarlarda olmaması ile istenilen zaman dilimlerinde laboratuvara ulaştırılmamış olması (süt ve su analizleri için alınan örneklerin en fazla 6 saat içerisinde, diğer gıda/yem örneklerinin ise 72 saatlik zaman diliminde laboratuvar tarafından analize alınmış olması gereklidir) ve numunelerin uygun olmayan koşullarda laboratuvara ulaştırılması gibi (soğuk zincir, etiket bilgilerindeki sıcaklık derecesi vb.) durumlardır (ISO 17728:2015).

\subsection{Analitik Süreç}

Mikrobiyolojik analizler için laboratuvara ulaştırılan numunelerin işlenmesi evresinde başlıca hata kaynakları; mikrobiyoloji laboratuvarı ortam şartları ve personelin hijyen kurallarına dikkat etmemesi, mikrobiyoloji laboratuvarında besiyeri hazırlanması sırasında dikkat edilmesi gereken kurallara riayet edilmemesi (sterilite, uygun hacim, otoklavlama, $\mathrm{pH}$ kontrolü), donanımın (otomatik pipet, terazi gibi) günlük, haftalık, aylık bakım programlarının yapılmaması, zamanında ölçümleme yapılmaması, yetersiz hacimde numune kullanılması, çalışma için gerekli ortam şartlarının sağlanmaması (sıcaklık, nem, havalandırma, sterilite), referans ve çalışma kültürü takiplerinin gerektiği şekilde yapılmaması, çalışma öncesi ve esnasında iç kalite kontrol takibinin etkin olarak gerçekleştirilmemesi, yeterlilik testlerine katılımda eksiklik veya hiç katılmama dolayısı ile laboratuvarın çalışma profili hakkında bir sonuca varamama, miadı geçmiş malzeme kullanılması, analizlerin güvenilirliği ve güncelliğin takip edilerek, doğru-güvenilir sonuç verilmemesi (Ulusal /Uluslararası stan- 
dartlar/ilgili rehber ya da kaynaklar vb.), test prosedür veya talimatlarına uyulmaması, mikrobiyoloji laboratuvarında kilit personelle alakalı yetkinlik ve akreditasyon analizlerinin gerçekleştirilmeden analizlere katkı sağlaması (deneyimsiz personel), analiz sonuçlarının kayıt altına alınmaması ya da unutulmasıdır (Türk 2012).

\subsection{Analiz Sonrası Süreç}

Analiz işlemleri tamamlandıktan sonra pozitif çıkan sonuçların izolasyon ve identifikasyonu, doğrulanması, onaylanması, sonuçların numune kabul birimi sistemine elektronik olarak ulaştırılması, rapor edilmesi ve sonuçların laboratuvar müdürü tarafından değerlendirilerek, onaylanması aşamalarını içerir. Analiz sonrası dönemdeki amaç, sonuçların doğru ve güvenilir bir biçimde, beklenen zaman diliminde raporlanmasıdır. Bu evrede görülebilecek başlıca hata kaynaklarl; gecikmiş ya da hiç rapor edilmemiş sonuçlar, elle yazılan sonuçlarda yapılabilecek hatalar, mikrobiyoloji ve numune kabul birimleri arasındaki iletişim sorunları, sonuçlarda uygunluk değer- lendirmelerinin yapılmaması ya da yanlış yapılması veya gerekli standart/yönetmelik/ilgili kit prosedürüne göre yapılmamış olması olabilir.

Çalışmada göz önüne alınan hata kaynakları personel, laboratuvar ve analiz bazında değerlendirilmiştir. FMEA analizinde, Şiddet (Ş), Olasılık (O) ve Risk Skorunun (E) belirlenmesi ve değerlendirilmesinde FMEA analizine katılan laboratuvar ekibi tarafından belirtilen hesaplamalardan faydalanılmıştır (Reid 2005).

Hatalara verilen toplam risk puanlarına bağIı değişimlere ait iki eş arasındaki farkın skorları Wilcoxon İstatistiki Önemlilik Testi ile değerlendirilmiştir $(p<0,05)$.

\section{Bulgular}

Yapılan değerlendirmelerde tespit edilen riskler ve sebepleri, mevcut kontroller, riskleri iyileştirmek için yapılan çalışmalar ve bu çalışmalara ilişkin açıklamalar ile iyileştirme çalışmaları sonucunda kazanılacak fırsatlar Tablo 2'de gösterilmiştir.

Tablo 2. Tespit edilen riskler ve yapılan müdahalelere ilişkin bilgiler.

\begin{tabular}{|c|c|c|}
\hline Sıra & Tespit Edilen Risk ve Sebep & Mevcut Kontroller \\
\hline \multirow[b]{2}{*}{$1^{a}$} & $\begin{array}{l}\text { Risk: Uygun olmayan numunenin gön- } \\
\text { derilmesi ile yanlış ve hatalı sonuç bil- } \\
\text { dirimi. }\end{array}$ & \multirow{2}{*}{$\begin{array}{l}\text { İlgili prosedür ve talimatlara } \\
\text { - uyularak, gerekli formların } \\
\text { tutulması. Gerekli noktalarda } \\
\text { sürekli takip ve gerekli bi- } \\
\text { rimlere eğitim yapılması. }\end{array}$} \\
\hline & $\begin{array}{l}\text { Sebep: Hatalı numune tanımı, numu- } \\
\text { nelerin yanlış etiketlenmesi ve gönde- } \\
\text { rilmesi, yanlış örnekleme, hatalı analiz } \\
\text { talepleri. }\end{array}$ & \\
\hline
\end{tabular}

Risk: Uygun olmayan numunenin kabul edilerek analize alınması ile yanlış ve ha- İlgili prosedür ve talimatlara talı sonuç bildirimi.

2 a Sebep: Uygun olmayan numune alımının yapılmış olması, uygun olmayan nakliye ve numune kabulün bu durumu fark etmeden numuneyi analize göndermesi.

Risk: Talep edilen analizlerin numunenin fiziksel koşullarına bağı olarak laboratuvar tarafından gerçekleştirilememesi,

3 a itibar kaybı.

Sebep: Numunenin laboratuvara getirilirken orijinal ambalajının veya sterilitesinin bozulması (soğuk zincir, etiket bilgilerindeki ısı derecesi v.b.).

Risk: Beklenenden daha fazla/ az mikroorganizmanın üremesi ile yanlış pozitif ya da yanlış negatif sonuçların verilmesi. Sebep: Numunelerin istenilen zaman

4 a dilimlerinde laboratuvara ulaştırılmamış olması (süt ve su analizleri için alınan örneklerin en fazla 6 saat içerisinde, diğer gıda/yem örneklerinin ise 72 saatlik zaman diliminde laboratuvar tarafından analize alınmış olması gereklidir) uyularak, gerekli formların tutulması. Gerekli noktalarda Sürekli takip ve birbiri ile kontrollü uygulamaların yapılması. yapılması.

\section{Açılamalar (İzleme Raporlama) / Fırsatlar}

Etkin bir şekilde Numune Kabul Prosedürünün oluşturulması veya mevcut prosedürün revizyonunun yapılması,

Uygun Olmayan Numunenin Reddi Formunun işletilmesi, Numune Kabul Prosedürünün müşteri tarafından güncel olarak bilinirliğinin sağlanması. / Müşteriye sunulan hizmet sürecinin kontrollü bir şekilde yürütülmesi sonucunda müşteri memnuniyetinin arttırılması.

Etkin bir şekilde Numune Kabul Prosedürünün oluştu-

İlgili prosedür ve talimatlara Etkin bir şekilde Numune Kabul Prosedürü veya mevcut uyularak, gerekli formların prosedürün revizyonunun yapılması ve Uygun Olmayan tutulması. Gerekli noktalarda Numunenin Reddi Formunun işletilmesi, Numune gerekli kişiler tarafından Kabul prosedürünün müşteri tarafından güncel olarak sürekli birbirini kontrol eden bilinirliğinin sağlanması. / Müşteriye sunulan hizmet kişi ve sistemlerin takibinin sürecinin kontrollü bir şekilde yürütülmesi sonucunda müşteri memnuniyetinin arttırılması ile itibar artışı.

Numune Kabul Prosedürünün müşteri tarafından günIilgili prosedür ve talimatlara cel olarak bilinirliğinin sağlanması, Uygun Olmayan uyularak, gerekli formların Numunenin Reddi Formunun işletilmesi, yapılması tutulması. Kritik süreçler ile elzem olan, acil vakalar için zorunlu olan durumlarda noktaların sürekli takibi ve (jandarma, savcılık, polis kanalıyla gelen numuneler) kritik kişilere işin önemi nok- rapora numune hakkında beyan düşülmesi / Müşteriye tasında eğitim verilmesi. sunulan hizmet sürecinin kontrollü bir şekilde yürütülmesi sonucunda müşteri memnuniyetinin arttırılması. 


\begin{tabular}{ll}
\hline Sıra & Tespit Edilen Risk ve Sebep \\
\hline Risk: Yanlış analiz sonucu hesaplama- \\
ları, yanlış pozitif/negatif sonuçların \\
verilmesi, yanlış kayıt tutulması ya da \\
unutulması.
\end{tabular}

5 a Sebep: Mikrobiyolojik analizler için uygun olmayan analist (kimyager, kimya mühendisi, orman mühendisi, v.b), personelin dalgın, üzgün, stresli olması, yeterli eğitim almamış, yetkin veya akredite olmayan analist

Risk: Uygun olmayan ortam koşulları ve analizler için hijyenik olmayan personel ile mikrobiyolojik analizlerin çalışılması ve doğru olmayan analiz sonuçlarının verilmesi.

Sebep: Hijyenik olmayan personel (ki-

6 a şisel hijyene özen göstermeme, terlik/ galoş kullanılmaması, önlük giyilmemesi, eldiven takma prensibi olmaması ve tek yönlü akışa dikkat edilmemesi, v.b). Laboratuvarın analizler için uygun olmayan ortam koşulları (ISI, hijyenik olmayan yüzey alanları, steril olmayan ekipman )

Risk: Mikrobiyoloji Laboratuvarında analiz sonuçlarında olacak yanlışlıklar, geriye dönük işlem yapılmaması

Sebep: Mikrobiyoloji laboratuvarında

7 a besiyeri hazırlanması (sterilite, uygun hacim, otoklavlama, pH kontrolü v.b.) kaynaklı analiz sonuçlarında olacak yanlışlıklar ve bu yanlışlıklar için geriye dönük işlem yapılamaması.

Risk: Anlık arıza durumlarında analizin gerçekleştirilemeyerek sonuç verilememesi, itibar kaybı

8 a Sebep: Zamanında ölçümleme yapılmaması, beklenmeyen cihaz/donanım arıza$\mathrm{sı}$, tanımlanmamış veya farkına varılamamış kalite kontrol arızası (otomatik pipet kalibrasyonunun bozulmuş olması, v.b.)

Risk: Gerekli durumlarda geri dönüş yapılamayan ve tekrarlanamayan analizler, talep edilen analiz sonuçlarının verilememesi ya da gecikmeli analiz sonuçlarının verilmesi.

$9^{\text {a }}$

Sebep: Analiz sonuçlarının kayıt altına alınmaması/ kayba uğraması

\section{Mevcut Kontroller}

İlgili prosedür ve talimatlara uyularak laboratuvar birimine uygun olan kişilerin analist olarak seçilmesi gerekli formların kritik kişiler tarafından düzenli olarak tutulması. Analistlerin yaptıkları iş ve takibi ile alakalı olarak ilgili formları tutarak kayıt altına almalarının sağ lanması. Gerekli görülen her noktada yetkin/yeterli kişiler tarafından eğitim verilmesi.

İlgili prosedür ve talimatlara uyularak, gerekli formların her adımda kritik kişiler tarafından tutulması. Kişilerin hijyen kurallarına uyma-

ları ile alakalı performans formlarının günlük olarak tutulması.

\section{Açıklamalar (İzleme Raporlama) / Fırsatlar}

Laboratuvar Müdürlüğü Çalışanları Görev Tanımları Prosedürü, Personel Yeterliliği ve Eğitimi Prosedürü, Personel Oryantasyon Planı, Yetkinlik Eğitim Planı, Yıllık Eğitim Planı, Personel Eğitim Değerlendirme Formlarının tam olarak yerine getirilmesinin sağlanmaSı, laboratuvarın ilgili bölümüne uygun analistin belirlenmesi, gerekli eğitim ve uygulamaların yaptırılarak yetkin/yeterli olup olmadığının kontrolü. Personellerin motivasyon kaybını engelleyen, yapılan iş ile alakalı formların her adımda takip sistemi ile devam ettirilmesi. / Personellerin yetkinliğinin izlenmesi ile bireysel performanslarında artış sağlanarak laboratuvar performansının (analiz sayılarının, analiz çeşitliliğinin ve araştırma faaliyetlerinin) arttırılması.

Mikrobiyoloji Ortam Şartları Talimatı,

Mikrobiyoloji Sterilizasyon Talimatı,

Ortam Şartları Takip Formu uygulamalarının disiplinli bir şekilde yerine getirilmesi. / Deney sonuçlarının doğruluğunun güvence altına alınması sonucunda müşteri memnuniyetinin korunması ve arttırılması.
Mikrobiyoloji laboratuva-

rında besiyeri hazırlanması ve hazırlık esnasında dikkat edilmesi gerekenlere yön veren prosedür ve talimatlatutulması ve kritik süreçlerde sonuçlarının doğruluğunun güvence altına alınması gereken kontrollerin yapıl- sonucunda müşteri memnuniyetinin korunması ve ması.

Günlük donanım, ısı vb. mik- Donanım Kullanma Talimatlarına uyum robiyoloji laboratuvarlarında ilgili donanımın kayıtlarının tutulduğu ilgili (kalibkritik öneme sahip noktaların anlatıldığı prosedür ve talimatlara her aşamada uyulması, kritik noktaların ilgili formlara gereken zaman dilimlerinde kayıt altına alınması.

\section{Mikrobiyoloji laboratuvar-}

larında kritik öneme sahip noktaların anlatıldığı prosedür ve talimatlara her aşamada uyulması, kritik noktaların ilgili formlara ve analiz kayıt defterlerine gereken zaman dilimlerinde kayıt altına alınması, cihaz çıktılarının zamanında alınması ve yedeklemelerin kritik nokta-

larda yapılması.

\section{Besiyeri Hazırlama Talimatı}

Su Kalite Kontrol Formu (suyun pH'sı, toplam $\mathrm{Cl}$, ağır metal varlığı, toplam canlı sayısı) ve Otoklav Kontrol Formlarının etkin bir şekilde kullanılması / Her adımarttırılması.

Donanım Kullanma Prosedürü ve ilgili donanımın kayıtlarının tutuldugu ilgili (kalib-
rasyon-bakım-onarım) formu ile Donanım Arıza Formunun düzenli olarak kullanılması, analiz sonuç raporuna analizin yapılamama nedeni hakkında açıklama yapılması / Her adımda donanımların kontrollerinin izlenmesi ile deney sonuçlarının doğruluğunun güvence altına alınması ve müşteri taleplerinin zamanında yerine getirilmesi sonucunda müşteri memnuniyetinin korunması ve arttırılması.

Deney Sonuçlarının Kalitesi Prosedürü ve

Kalite Kayıtlarının Kontrolü Talimatının etkin bir şekilde uygulanması. / Her adımda yapılan kayıtlar ile güvenilir ve geriye dönük izlenebilir sonuçların elde edilmesi, deney sonuçlarının doğruluğunun güvence altına alınması sonucunda müşteri taleplerinin zamanında yerine getirilerek müşteri memnuniyetinin korunması ve artırılması. 


\begin{tabular}{ll}
\hline Sıra & Tespit Edilen Risk ve Sebep \\
\hline Risk: Yanlış analiz sonucu, tespit edi- \\
len mikroorganizma sayıları için yanlış \\
uygun/uygunsuzluk değerlendirmeleri \\
sonucunda üretici aleyhinde işlemlerin \\
gerçekleşmesine neden olunması
\end{tabular}

10 a Sebep: Kritik analiz sonuçlarının yorumlanmasında ilgili yönetmelik ve/veya dokümanların yanlış değerlendirilmesi personelin analiz aşamasında yaptığı hatalar, yetkin olmayan personelin analizlerde görevlendirilmesi.

\section{Mevcut Kontroller}

İlgili teknik personelin yetkin ve yeterli olmasının yanında İlgili yönetmelik, prosedür, talimatlara uyarak, gerekli işlemlerin yapılmasını sağlaolarak gerçekleştirilmesi. ması. Tüm bunların kontrollü

\section{Açıklamalar (İzleme Raporlama) / Fırsatlar}

Deney Sonuçlarının Kalitesinin Prosedürü, Deney Metotlarının Geçerli Kılınması Prosedürü ve Talimatı, Uygun Olmayan Deney İşinin Kontrolü Prosedürü, Düzeltici Faaliyet Prosedürü, Mikrobiyoloji Laboratuvarı iç Kalite Kontrol Talimatı, Mikrobiyoloji Birimi Deney Metotlarının Geçerli Kılınması Talimatına Uyum Sağlanması, Düzeltici Faaliyet ve Uygun Olmayan Deney Bildirim Formunun etkin bir şekilde işletilmesi. / Personellerin yetkinliğinin her aşamada izlenmesi ile bireysel performanslarında artış sağlanarak laboratuvar performansının (analiz sayılarının, analiz çeşitliliğinin ve araştırma faaliyetlerinin) arttırııması, doğru ve hızlı bir şekilde analizlerin sonuçlandırılarak müşteri memnuniyetinin arttırılması.

\section{Risk: Raporlamada gecikmeler yaşanması İlgili prosedür ve talimatlara} uyularak, ilgili formların

Sebep. Veri yedeklemelerinin (cihaz liz sonucu, yetkinlik, v.b.) yapılmamas veya eksik uygulanması

Risk: Başlayan hataların sistematik ve düzenli olarak tekrar etmesi, sebep/sebeplerin ortadan kaldırılamaması, analiz sonuçlarının kalite ve güvencesinin teh13 a dit altında olması.

Sebep: Doğru olmayan ya da eksik düzeltici faaliyetler. tutulması. Gerekli oldukça sistemde güncellemeler yapılması, veri tabanlarının iyileştirilmesi, alternatif enerji kaynakları ile destek sağlanması.

Mikrobiyoloji laboratuvarlarının en önemli noktalarını içeren ilgili prosedür ve talimatlara muhakkak uyulması, gerekli kayıtların gerekli zamanlarda tutulması, kritik noktalarda kritik önem arz eden analist/analistlere başvurularak beyin fırtınasının gerçekleştirilmesi, yetkin/ yeterli olmayan analistin analizlere katılmaması ve karar sürecinde bulunmaması.

Numuneye Uygulanan İşlemler Prosedürü Düzeltici Faaliyet ve Uygun Olmayan Deney Bildirim Formu / Daha hızlı ve kontrollü sonuçlar ile müşteri memnuniyetinin arttırılması.

Kalite Kayıtlarının Kontrolü Talimatı,

Uygun Olmayan Deney İşinin Kontrolü Prosedürü,

Düzeltici Faaliyet Prosedürü

Düzeltici Faaliyet ve Uygun Olmayan Deney Bildirim

Formlarının, personel yetkinliğinin, veri yedeklemelerinin etkin bir şekilde izlenmesi. / Kalite yönetim sistemi gerekliliklerinin ve dokümanlarının etkin bir şekilde izlenmesi ile laboratuvar süreçlerinin doğru yönetilmesi sonucunda laboratuvar performansının (analiz sayılarının, analiz çeşitliliğinin ve araştırma faaliyetlerinin) arttırılması.

Deney Sonuçlarının Kalitesinin Prosedürü, Deney Metotlarının Geçerli Kılınması Prosedürü ve Talimatı, Uygun Olmayan Deney İşinin Kontrolü Prosedürü,

İlgili prosedür ve talimatlara uyularak, ilgili formların tutulması. Sürekli kontrollü takiplerin yapılması.
Düzeltici Faaliyet Prosedürünün etkin bir şekilde izlenmesi, Düzeltici Faaliyet ve Uygun Olmayan Deney Bildirim Formunun katılımcı yöntemlerle doğru bir şekilde yapılarak işlenmesi / Kalite yönetim sistemi gerekliliklerinin ve dokümanlarının etkin bir şekilde izlenmesi ile laboratuvar süreçlerinin doğru yönetilmesi sonucunda laboratuvar performansının (analiz sayılarının, analiz çeşitliliğinin ve araştırma faaliyetlerinin) arttırılması.

Not: a. Eski etki, olasılık ve risk puanı sırasıyla 5, 2 ve 10'dur. Riskin önem düzeyi "orta düzey" olarak belirlenmiştir. Düzeltmelerden sonra yeni etki, olasılık ve risk puanı sırasıyla 5, 1 ve 5 bulunmuştur. Riskin önem düzeyi "düşük düzey" olarak belirlenmiştir. b. Eski etki, olasılık ve risk puanı sırasıyla 4, 2 ve 8'dur. Riskin önem düzeyi "orta düzey" olarak belirlenmiştir. Düzeltmelerden sonra yeni etki, olasılık ve risk puanı sırasıyla 4, 1 ve 4 bulunmuş ve riskin önem düzeyi "düşük düzey" olarak belirlenmiştir.

Tablo 3. Müdahalenin risk puanlarına olan etkisi.

\begin{tabular}{llllll}
\hline Puanlama zamanı & Ortalama risk puanı & Standart sapma & Standart ortalama hata & t & p değeri \\
\hline Çalışma Öncesi & 9,84 & 0,55 & 0,15 & 64 & p $<0,05$ \\
Çalışma Sonrası & 4,92 & 0,27 & 0,27 & \\
\hline
\end{tabular}

Risk puanlamaları karşılaştırıldığı zaman istatistiki açıdan fark olduğu görülmüştür $(p<0,001)$. Çalışma öncesi ortalama risk puanı ile standart sapma değerinin 9,84 $\pm 0,55$ puan olduğu tespit edilmiş, çalışma sonrası ise bu değerler 4,92 $\pm 0,27$ puan olarak hesaplanmış, bu anlamda risk puanlarının azaldığı anlaşımıştır. 4 ile10 puan arasında dağılım gösteren risk puanlarının yapılan iyileştirmeler 
ve risk analizinden sonra 5 civarında toplandığı, 17 . ve 23. risklerin ise 4 puana düşerek iyileştiği görülmektedir.

\section{Tartışma ve Sonuç}

Bu çalışmada örnek bir risk analizinin hangi noktalara dikkat edilerek yapıldığı belirtilerek anlatılmaya çalışılmıştır. Araştırma sonucunda, risk tanımlamaları yapılmamış ve dolayısı ile hiçbir şekilde etkisi ile şiddeti bilinmeyen önceki sistem ile olası tüm risk tanımlamaları yapılmış ve etkisi ile şiddeti hesaplanarak skor elde edilen sistem arasındaki Risk Skoru sonuçları değerlendirmeye alınmıştır.

Çalışmamıza benzer şekilde, Aksay ve ark. (2011) tarafından bir kamu hastanesinde laboratuvar sürecine ilişkin yapılan Hata Türleri ve Etkileri Analizinde (HTEA) kan tahlili çalışmaları ile ilgili yedi adet potansiyel hata tespit edilmiştir. Laboratuvardaki cihazların kullanımı esnasında meydana gelebilecek potansiyel hatalar ana başlığından, ideal çevre şartlarının gerçekleştirilmemiş olması gibi (sıcaklık, nem, toz $\mathrm{vb}$.) nedenlerle meydana gelen potansiyel hatalar olup, Risk öncelik sayısının (RÖS) 600 olduğu hesaplanmış ve en yüksek risk puanına sahip olduğu görülmüştür. Bu yüksek risk, klima, hava temizleyici, nemölçer, termometre kullanılmasının önerilmesi yoluyla çok büyük oranda düşürülmüştür (RÖS: 40). Ayrıca distile su kullanılmaması sonucu oluşabilecek RÖS puanı 500 olarak tespit edilmiş olup, distile su cihazı kalitesinin ölçümlenebileceği su analiz cihazlarının kullanılmasının sağlanması yoluyla risk puanının 100 'e düşürülebileceği belirtilmiştir. Laboratuvar süreçlerine ait bu risk analizinde RÖS çarpım değerlerinin yüksek olmasının şiddet puanlarının yüksek hesaplanmasından kaynaklanmış olduğu belirtilmektedir. Bu çalışmada da yapılan müdahale etkisi açık olarak görülmüştür.

Risk analizi amacıyla tespit edilen riskler, FMEA yöntemi kullanılarak hızlıca analiz edilebilir. Riski ortadan kaldırmak veya en aza indirmek için risk oluşmadan önce olası hataları belirleyen tanımlanmış sistematik işlem veri ve dokümanları kullanılması gerektiği daha önce belirtilmiștir (Uslu 2016). Çalışmamızda da anılan yöntem kullanılarak risk analizi kolay ve hızlı bir şekilde yapılabilmiştir.

Alınan önlemlerin etkinliğinin değerlendirilmesinde, hataları azaltma çabalarının (düzeltici ve önleyici faaliyetler) başarısı izlenmelidir. Değerlendirme için belirlenen kalite göstergeleri (müşteri şikayet sayısı, kalibrasyon verileri, iç ve dış kalite kontroller vb.) kullanılabilir. ISO gerekliliklerine uygun süreçleri yürütebilmek için kurum genelinde uygun ve etkin personel eğitimi sağlanmalıdır (Rin 2009; Vasilnakova 2018). Bu anlamda alanında yetkin veya akredite olmayan personel, laboratuvar içi iletişim ve genel iş birliğini içeren alanlar ile tüm sistemin genel test sürecinin iyileştirilmesine dahil olması gerekmektedir. Eğitimin etkinliği çalışmamızın da temelini oluşturmuştur.

Gıda ve yem numunelerinin çalışıldığı mikrobiyoloji laboratuvarlarında çalışanları yaptıkları işin gereği olarak birtakım potansiyel tehlikelere maruz kalmakla beraber aynı risklerden numunelerin de etkilenebileceği düşünülmelidir. Güvenli çalışmanın temel unsuru olan çalışma planları (biyolojik hijyen, patojenlerle çapraz bulaşma) oluşturulmalı ve uygulamada azami düzeyde planlara uyulmalıdır. Bunun için, risk kaynaklarına ilişkin kontrol mekanizmalarının ilgili ulusal ve/veya uluslararası güncel standartlar kullanılarak çeşitli prosedür, talimat ve formlarla düzenli olarak işletilmesi, belirli periyotlarla kontrollerinin alanlarında yetkin olan personel ya da personeller tarafından yapılması gerekmektedir.

\section{Kaynaklar}

1. Aksay K. (2003) "Hastanelerde Risk Yönetimi ve Bağlantılı Fonksiyonlar: İstanbul Memorial Hastanesi Örneği", Yüksek Lisans Tezi, Anadolu Üniversitesi Sosyal Bilimler Enstitüsü. Eskişehir.

2, Aksay K, Orhan F, Kurutkan M. (2012) Sağlık Hizmetlerinde Bir Risk Yönetimi Tekniği Olarak FMEA: Laboratuvar Sürecine Yönelik Bir Uygulama. Sağlıkta Performans ve Kalite Dergisi. 4, 121-142.

3, Bolayırlı M. (2013) Laboratuvar süreçlerinde hata kaynakları. HA Sönmez ed. Hastalıkların izlenmesinde Biyokimya Laboratuvarı. İstanbul: İstanbul Üniversitesi Cerrahpaşa Tıp Fakültesi Sürekli Tıp Eğitimi Etkinlikleri Sempozyum Dizisi No:81, 17-24.

4, ECRI (2003) Risk and Quality Management Strategies, Healthcare Risk Control. Volume 2, March.

5, EUROLAB (2017) Cook Book: Doc No. 18 Risk Based Approach, p.5.

6, Griffin D. (2011) Hospitals. What They Are and How They Work, Third Edition, Jones and Bartlett Publishers, Inc, p.423.

7. ISO (2015) ISO/TS 17728: 2015 GIda zinciri mikrobiyolojisiGıda ve hayvan yemlerinin mikrobiyolojik analizlerde numune alma teknikleri.p.12

8. ISO (2017) ISO 17025:2017 General Requirements for the Competence of Testing and Calibration Laboratories.

9. ISO (2018) ISO 31000:2018 Risk Management-Guidelines. 2018 (3).p.6

10. Lee KM, Choi YJ, Park KH, Jang WJ. (2014) The Management of Laboratory Biological Safety in Korea. J Bacteriology and Virology. 44 (4), 342-351.

11. Mc Dermott RE, Mikulak RJ, Beauregard MR. (2009) The Basics of FMEA, CRC Press, New York.

12. Neogi SS, Mehndiratta M, Gupta S, Puri D. (2016) Preanalytical phase in clinical chemistry laboratory. J Clin Sci Res. 5(3), 171-178. 
13. Özata M, Altunkan H. (2010) Hastanelerde tıbbi hata görülme sıklıkları, tıbbi hata türleri ve tıbbi hata nedenlerinin belirlenmesi: Konya Örneği. Tıp Araştırmaları Dergisi. 8 (2),100-111.

14. Pillay A, Wang J. (2003) Modified failure mode and effects analysis using approximate reasoning. Reliability Engineering and System Safety. 79, 69-85.

15. Reid RD. (2005) "FMEA-Something Old, Something New", Quality Progress, May, 2005. (http://asq.org/quality-progress/2005/05/standards-outlook/fmea-something-old-something-new.html) Erişim Tarihi: 08.05.2020

16. Rejda EG. (2010) Principles of Risk Management and Insurance, Tenth Edition. Boston: Addison Wesley, p.748.

17. Rin DG, (2009) Pre-analytical workstations: A tool for reducing laboratory errors. Clinica Chimica Acta. 404(1), 68-74.
18. TS EN ISO 31010:2017 Risk Yönetimi- Risk değerlendirme teknikleri. p.70

19. Türk M. (2012) Ege Üniversitesi Tıp Fakültesi, Halk Sağlığı Anabilim Dalı. Bir Üniversite Hastanesi Mikrobiyoloji Laboratuvarlarında Risk Değerlendirmesi. Türk Tabipleri Birliği Mesleki Sağlık ve Güvenlik Dergisi, 27-43.

20. Uslu MK. (2016) Laboratuvar Çalışanlarının Karşılaştığı Fiziksel Risklerin Hata Türü ve Etkileri Analizi (HTEA) ile Değerlendirilmesi. Bir Üniversite Hastanesi Örneği. Selçuk Üniversitesi Sağlık Bilimleri Enstitüsü, Sağlık Yönetimi Anabilim Dalı, Yüksek Lisans Tezi, Konya.

21. Vasilnakova A. (2018). Risk Management in Accredited Testing Laboratories. Katalinic B. ed Proceedings of the 29th DAAAM International Symposium. DAAAM International, Vienna. pp.1071-1075. 